\title{
PEMBANGUNAN KARAKTER KEARIFAN LEGENDA SARIP TAMBAK OSO BAGI GENERASI
}

\author{
${ }^{(1)}$ Joko Susilo dan Niko Fediyanto ${ }^{(2)}$ \\ ${ }^{(1,2)}$ Dosen Fakultas Ekonomi dan Bisnis \\ Universitas Muhammadiyah Sidoarjo Indonesia \\ Email: ${ }^{(1)}$ jokosusilo1@ umsida.ac.id, fediyantoniko@gmail.com ${ }^{(2)}$
}

\begin{abstract}
ABSTRAK
Kegiatan mendongeng dapat diartikan sebagai proses transfer ilmu dari generasi ke geenerasi, namun terkadang proses tersebut terputus karena beberapa faktor pengganggu dari luar budaya masyarakat. Oleh karena itu dalam program ini dirancang tentang kegiatan mendongengkan cerita "Sarip Tambak Oso" yang kami peragakan dalam bentuk pertunjukan Wayang Sarip. Desain yang digunakan adalah model wayang eksperimental dari bahan kertas menjadi tokoh-tokoh dalam legenda Sarip Tambak Oso. Tema yang diangkat adalah pengembangan asesmen serta intervensi untuk kebahagiaan manusia. Pertunjukan yang berisi tentang muatan-muatan kearifan lokal tersebut kami tujukan kepada dua generasi yaitu anak-anak usia dini dan anak-anak remaja. Anak-anak usia dini tersebut adalah siswa-siswi TK Dharmawanita Persatuan Terung Kulon Krian. Tujuannya adalah: (1) mengembangkan kreasi pembuatan dan pementasan wayang legenda bagi pengusul dan peserta, (2) membantu menciptakan pemahaman dan kecintaan peserta PKM terhadap makna cerita rakyat "Sarip Tambak Oso", (3) meningkatkan keterampilan berpikir, memaknakan legenda dan menulis artikel bagi pengusul program.
\end{abstract}

Kata Kunci: kearifan lokal, kesadaran budaya, generasi muda

\section{ABSTRACT}

Storytelling is a way to transfer knowledge from generation to generation, but sometimes the process is interrupted due to some disturbing factors from outside the cultural society. This program is designed to generate the activity of storytelling with "Sarip Tambak Oso" folklore as the medium, which is packed in the form of Wayang Sarip (puppet) show. The design used is an experimental wayang model of paper material into characters in the legend Sarip Tambak Oso. The theme of this program is the development of assessment and intervention for human happiness. The performances contains the contents of local wisdom, which is aimed to two generations, which are the early childhood and adolescent children. These early childhood children are students of kindergarten Dharmawanita Kesung Kulon Krian, and the teenagers are members of Karang Taruna Perumahan MCA, RW 5 Boro Tanggulangin village. The objectives are: (1) to develop the creation and making of puppet show legend for the proponents and participants, (2) to help create understanding and love of PKM participants to the meaning of folklore "Sarip Tambak Oso", (3) improving analytical skill, using legend and writing articles for the program proponent.

Keywords: local wisdom, cultural awareness, young generation

\section{PENDAHULUAN}

Cerita rakyat "Sarip Tambak Oso" adalah legenda asli yang lahir di Sidoarjo pesisir timur. Bayak keterangan masyarakat menyebutkan berasal dari desa Tambak Oso (Tambak Sawah) kecamatan Waru. Cerita tersebut merupakan pengetahuan turuntemurun yang telah membentuk karakter masyarakat pesisir timur Sidoarjo yang hidup di wilayah tambak. Secara kasat mata cerita Sarip lahir sebagai bentuk perlawanan terhadap penjajah Belanda dan perlawanan 
terhadap kezaliman secara umum. Ketika dibaca secara hermeneutik cerita tersebut mengandung muatan yang penting bagi generasi muda misalnya: bakti dan cinta terhadap orang tua (utamanya ibu), cinta terhadap lingkungan masyarakat dan secara luas cinta bakti terhadap bangsa.

Generasi muda sangat membutuhkan pengetahuan tentang kearifan lokal guna membentuk karakter asli budaya masyarakatnya. Karena pengetahuan tersebut adalah ilmu yang diwariskan oleh nenek moyang yang sudah disesuaikan dengan kondisi masyarakatnya. Oleh karena itu siswa-siswi TK Dharmawanita Persatuan Terung Kulon Krian yang dibesarkan di Sidoarjo harus mampu menerapkan nilai-nilai dan pengetahuan yang tersimpan di dalam cerita "Sarip Tambak Oso".

Pengetahuan tentang nilai-nilai kehidupan atau kearifan lokal yang dihasilkan oleh budaya asli bangsa lndonesia semakin lama semakin pudar bahkan sirna dari pemikiran generasi muda. Kepudaran pemahaman nilai tersebut juga mengancam generasi di dua lokasi yang kami jadikan mitra, yaitu remaja di Perumahan MCA Tanggulangin dan anak-anak usia dini di desa Terung Kulon, Krian. Generasi muda di desa Terung dan Perumahan MCA belum menyadari bahwa di kebudayaan masyarakatnya tersimpan muatan pengetahuan kearifan lokal yang bernilai tinggi. Solusi yang ditawarkan yaitu dengan pementasan wayang kreasi perpaduan seni klasik dan modern akan menarik perhatian generasi tersebut untuk menerapkan nilainilai kearifan lokal.

Pementasan teater boneka dapat menarik perhatian anak-anak. Muatan nilainilai positif yang tersimpan di dalam pementasan tersebut akan diterima anak-anak secara menyenangkan, berbeda dengan ketika anak-anak dinasihati terus menerus melaui dialog biasa. Dengan diadakannya sosialisai cerita Sarip ini, generasi muda di desa Terung dan Perumahan MCA akan menyadari bahwa di kebudayaan masyarakatnya tersimpan muatan pengetahuan kearifan lokal yang bernilai tinggi. Pementasan wayang kreasi perpaduan seni klasik dan modern akan menarik perhatian generasi tersebut untuk menerapkan nilai-nilai kearifan lokal dalam kehidupan sehari-hari. Bahasa pertunjukan yang digunakan adalah bahasa Indonesia sehari-hari diselingi logika bahasa Jawa. Musik pengiring adalah musik yang ceria dan lagu-lagu yang dikenal anak-anak, dengan menyisipkan filosofi musik karawitan Jawa. Di dalam karawitan Jawa mengandung nilainilai lslam. Pada tahap awal perkembangan lslam di Pulau Jawa, Islam mendorong perkembangan musik Jawa. Sebagaimana dijelaskan dalam Serat Babad Nitik, gamelan dan wayang disajikan berdampingan dengan musik lslam (Sumarsam, 2003:48).

Target luaran dalan pengabdian kepada masyarakat ini adalah: (1) alat peraga berupa wayang kreasi penokohan dalam cerita "Sarip Tambak Oso", (2) pemahaman dan kecintaan peserta PKM terhadap makna cerita rakyat "Sarip Tambak Oso", dan (3) hasil program akan disebarluaskan dalam bentuk artikel yang dipublikasikan pada jurnal nasional atau prosiding atau media masa atau didaftarkan HaKI.

\section{METODE PELAKSANAAN}

Awal mula tahapan ini adalah cerita lisan dari masyarakat yang tinggal di Gunung Anyar Surabaya bahwa makam Sarip berada di Tambak Oso (Tambak Sawah Waru). Ada pula sumber lisan yang mengatakan bahwa Sarip dulu diyakini tinggal di Oso Wilangon Surabaya. Dari 2 sumber lisan yang didapatkan tersebut kami pengusul memutuskan untuk memperdalam informasi bahwa Sarip berasal dari Tambak Sawah Sidoarjo. Masyarakat penutur mengatakan bahwa Sarip adalah pemuda pemberani yang melawan penjajah Belanda dan antekanteknya, ketika ia ditembak mati akan hidup lagi ketika ibunya memanggil "Sarip!"

Pada tahap pencarian konsep selanjutnya kami melakukan pembacaan lakon Sarip pada buku yang ditulis Djamil Suherman (1985). Buku tersebut juga menceritakan hal yang sama yaitu tentang nilai-nilai bakti Sarip terhadap ibunya, nilai tanggung jawab terhadap masyarakat sekitar, 
dan kecintaan terhadap tanah air. Mitologi Jawa pada hakikatnya merupakan salah satu akar budaya Jawa yang dengannya manusia Jawa mencari jawaban atas persoalan kehidupan yang dihadapi. Mitologi pada mulanya memiliki fungsi sakral sebagai pengendali moral dan pikiran khalayak pendukungnya dalam menanggapi dan memahami alam semesta (Zaidan, 2002: 8 $10)$.

Pembuatan ini dilakaukan oleh tim dosen dan mahasiswa Umsida selanjutnya mengajak anggota Karang Taruna MCA RW 5 desa Boro untuk memperbanyak farian. Bahan dasar yang digunakan adalah kertas Art Karton 300 gsm. Pewarnaan menggunakan pilihan warna yang ceria dengan tujuan untuk menarik perhatian anakanak.

Latihan awal adalah menggerakkan wayang kartun dan pengucapan karakter. Wayang digerakkan oleh beberapa orang. Musik pengiring adalah musik digital diiringi musik manual untuk penekanan. Filosofi musik karawitan Jawa yang disebut di atas adalah untuk membangun irama pemikiran bagi peserta PKM. Keselarasan nada macapat akan digunakan untuk membangun karakter irama yang selaras dengan rasa Jawa. Tembang macapat mempunyai metrum yang mengatur guru gatra: cacahing gatranipun sekar (jumlah baris tembang, yang terdapat pada satu pada(bait)), guru lagu: dhongdhinging swara ing wekasaning gaatranipun sekar (bunyi pada akhir baris), guru wilangan: cacahing wanda ing gatragatraning sekar (jumlah sukukata tiap baris tembang) (Susastina, 2009:3).

Pementasan akan dilakukan dilakukan di TK Dharma Wanita Persatuan Terung Kulon Krian Sidoarjo. Pementasan di lokasi pertama dilakukan langsung oleh tim dari Umsida (Universitas Muhammadiyah Sidoarjo). Setelah pementasan akan mengajak peserta (anak-anak) untuk berkomentar tentang nilai-nilai tauladan yang bisa diambil.

Pementasan akan disesuaikan dengan bahasa yang lazim digunakan oleh masyarakat Sidoarjo, (basane arek Darjo).
Masyarakat Sidoarjo berbahasa Jawa berbeda dengan cara berbahasanya masyarakat Yogyakarta atau Surakarta. Perbedaan metrum dan perbedaan penamaan pupuh di atas salah satu penyebabnya adalah perbedaan kosakata yang dikuasai antara masayarakat Jawa pesisir dengan kosakata yang dikuasai pujangga kraton Mataram atau Surakarta. Bahasa Jawa pesisiran adalah bahasa yang digunakan masyarakat Jawa di pesisir utrara pulau Jawa (Hutomo, 1984:41).

Program ini selaras dengan program

'Desa Melangkah'. Desa Melangkah merupakan salah satu program penting yang dirintis Umsida untuk mengembangkan potensi desa-desa di Sidoarjo. Tujuan program tersebut pertama, meningkatkan kapasitas untuk pemerintah desa-desa di Sidoarjo dan masyarakatnya dalam rangka memperkaya dan meningkatkan pelayanan publik. Kualitas partisipasi masyarakat dalam pembangunan desa sangat berperan penting pada perkembangan sebuah negara. Kedua, menyelenggarakan kegiatan nasional, Usaha Kecil Menengah (UKM) yang nama generiknya digunakan untuk memajukan kemandirian desa, terutama di sidoarjo, akan diselenggarakan di luar Jawa Timur diantaranya, Bandung, Jogja dan beberapa kota lain. Ketiga, desa-desa mendapat pendampingan langsung dari Umsida. Keseriusan Umsida mendampingi desa dalam bidang pendidikan, hukum, ekonomi, politik dan sosial, kesehatan jiwa dan raga, hingga teknologi dan keagamaan. Umsida mempunyai keseriusan dalam pembentukan Sumber Daya Manusia (SDM) desa yang tangguh, mandiri.

\section{HASIL DAN PEMBAHASAN}

Pengetahuan awal cerita lisan tersebut didapatkan dari masyarakat yang tinggal di Gunung Anyar Surabaya bahwa makam Sarip berada di Tambak Oso (Tambak Sawah Waru). Ada pula sumber lisan yang mengatakan bahwa Sarip dulu diyakini tinggal di Oso Wilangon Surabaya. Dari 2 sumber lisan yang didapatkan tersebut kami pengusul memutuskan untuk memperdalam informasi bahwa Sarip berasal dari Tambak Sawah Sidoarjo. Masyarakat 
penutur mengatakan bahwa Sarip adalah pemuda pemberani yang melawan penjajah Belanda dan antek-anteknya, ketika ia ditembak mati akan hidup lagi ketika ibunya memanggil "Sarip!". Tahap pencarian konsep selanjutnya dilakukan terhadap pembacaan lakon Sarip pada buku yang ditulis Djamil Suherman (1985). Buku tersebut juga menceritakan hal yang sama yaitu tentang nilai-nilai bakti Sarip terhadap ibunya, nilai tanggung jawab terhadap masyarakat sekitar, dan kecintaan terhadap tanah air. Pembuatan Wayang Sarip dilakaukan oleh tim dosen dan mahasiswa Umsida menggunakan Pewarnaan menggunakan pilihan warna yang ceria dengan tujuan untuk menarik perhatian anakanak.
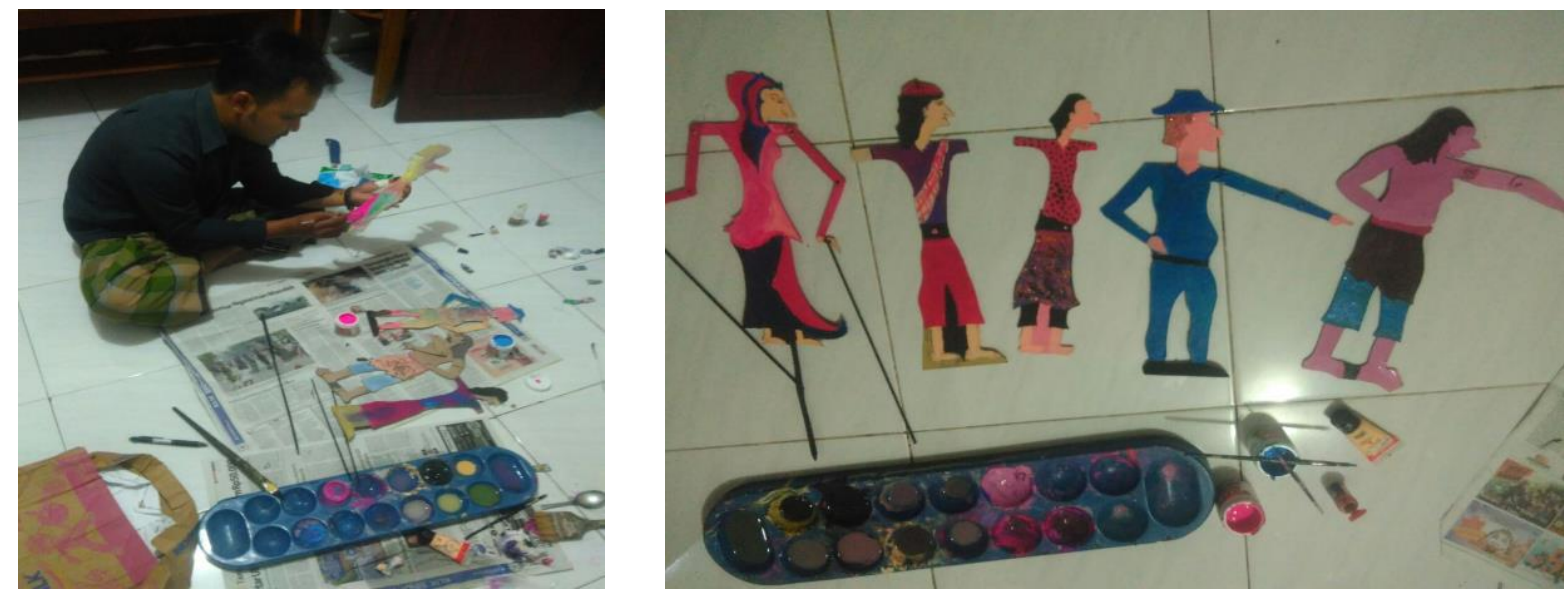

Gmbar 1, 2 Pembuatan Wayang Sarip

Latihan Pementasan awal adalah menggerakkan wayang kartun dan pengucapan karakter. Wayang digerakkan oleh beberapa orang. Musik pengiring adalah musik digital diiringi musik manual untuk penekanan. Filosofi musik karawitan Jawa yang disebut di atas adalah untuk membangun irama pemikiran bagi peserta PKM. Keselarasan nada macapat akan digunakan untuk membangun karakter irama yang selaras dengan rasa Jawa. Tembang macapat mempunyai metrum yang mengatur guru gatra: cacahing gatranipun sekar (jumlah baris tembang, yang terdapat pada satu pada(bait)), guru lagu: dhong-dhinging swara ing wekasaning gaatranipun sekar (bunyi pada akhir baris), guru wilangan: cacahing wanda ing gatra-gatraning sekar (jumlah sukukata tiap baris tembang) (Susastina,

2009:3
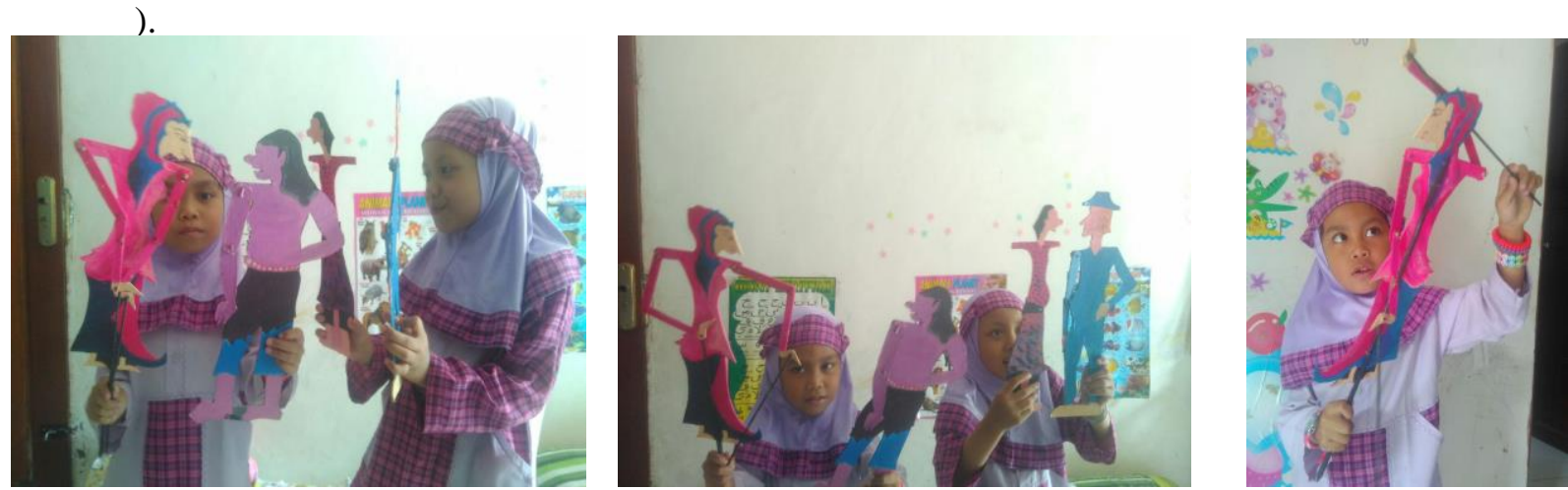

Gambar 3, 4, 5: Latihan Bersama siswa-siswa TK Dharma Wanita Persatuan I Terung Kulon 
Pementasan dilakukan dilakukan di TK Dharma Wanita Persatuan Terung Kulon Krian. Pementasan di lokasi pertama dilakukan langsung oleh tim dari Umsida. Setelah pementasan akan mengajak peserta (anak-anak) untuk berkomentar tentang nilainilai tauladan yang bisa diambil. Pementasan disesuaikan dengan bahasa yang lazim digunakan oleh masyarakat Sidoarjo. Masyarakat Sidoarjo berbahasa Jawa berbeda dengan cara berbahasanya masyarakat Yogyakarta atau Surakarta. Perbedaan metrum dan perbedaan penamaan pupuh di atas salah satu penyebabnya adalah perbedaan kosakata yang dikuasai antara masayarakat Jawa pesisir dengan kosakata yang dikuasai pujangga kraton Mataram atau Surakarta. Bahasa Jawa pesisiran adalah bahasa yang digunakan masyarakat Jawa di pesisir utara pulau Jawa, termasuk Sidoarjo.

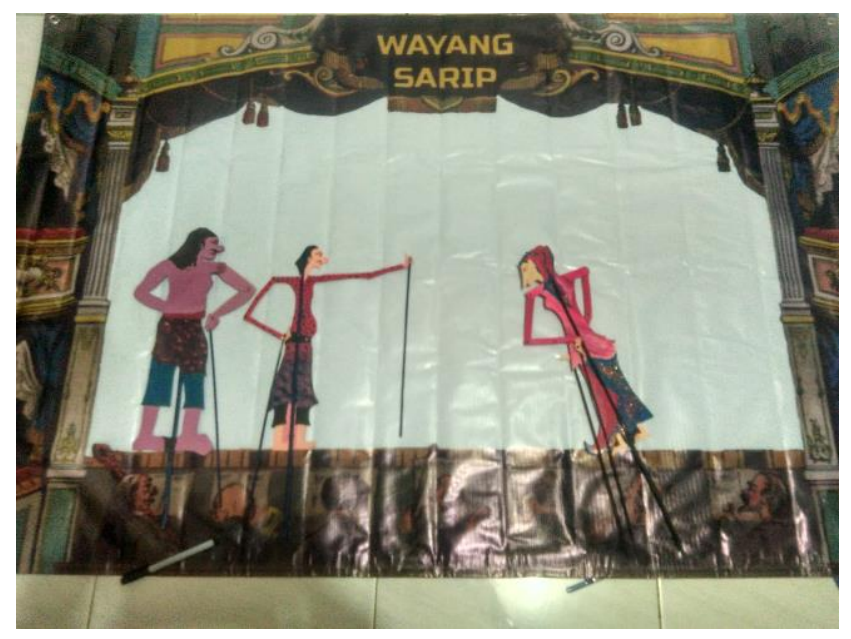

Gambar.6 Persiapan Pementasan
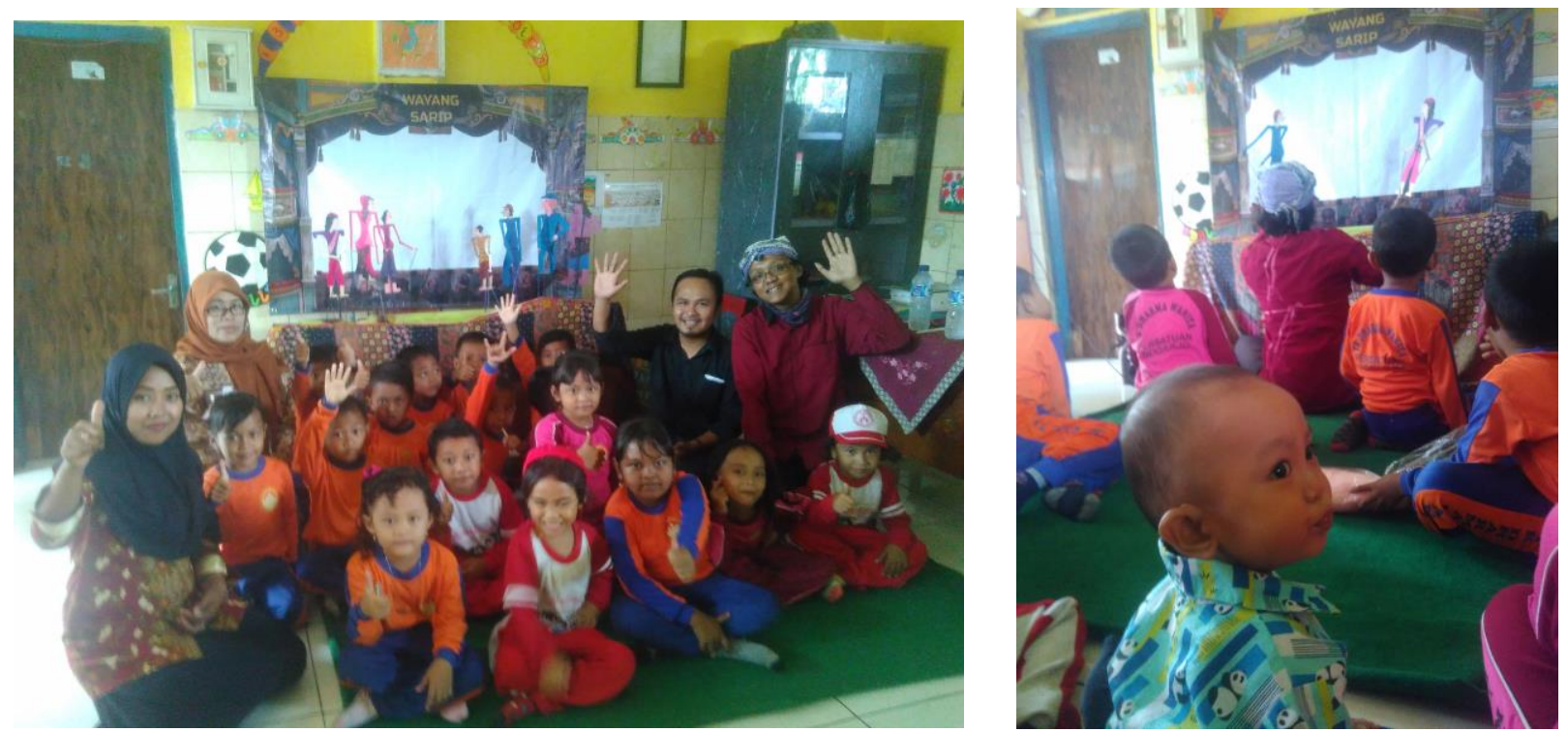

Gambar 7, 8 Pementasan Wayang Sarip di TK Dharma Wanita Persatuan I Terung Kulon 


\section{Tahapan Program}

Program kegiatan Pengabdian Kepada Masyarakat Wayang Sarip diringkas pada tabeltabel di bawah ini

\section{Tabel 1: Kegiatan Tahap Pertama}

Bulan : Desember 2017

\begin{tabular}{|c|c|l|l|}
\hline No. & Tanggal & \multicolumn{1}{|c|}{ Kegiatan } & \multicolumn{1}{|c|}{ Catatan Kemajuan } \\
\hline 1. & 1 s.d. 10 & $\begin{array}{l}\text { Diskusi penentuan kesatuan } \\
\text { objek }\end{array}$ & $\begin{array}{l}\text { Diskusi tentang titik fokus cerita Sarip } \\
\text { yang akan menjadi topik utama }\end{array}$ \\
\hline 2. & 11 s.d. 17 & Pengumpulan data program & Pembacaan dan wawancara \\
\hline 3. & 21 s.d. 25 & Proses penulisan naskah & $\begin{array}{l}\text { Adaptasi cerita Sarip disesuaikan dengan } \\
\text { kebutuhan anak-anak (lampiran 4) belum } \\
\text { selesai diadaptasi seluruhnya }\end{array}$ \\
\hline 4. & 26 s.d. 27 & Proses pengumpulah bahan & Pengumpulan bahan dasar \\
\hline 5. & 28 s.d. 31 & $\begin{array}{l}\text { Proses Pembuatan Wayang } \\
\text { Sarip }\end{array}$ & Proses pembuatan ada di \\
\hline
\end{tabular}

Tabel 2: Kegiatan Tahap Kedua

Bulan : Januari 2018

\begin{tabular}{|c|c|l|l|}
\hline No. & Tanggal & \multicolumn{1}{|c|}{ Kegiatan } & $\begin{array}{l}\text { Catatan Kemajuan } \\
\text { (berisi data yg diperoleh, keterangan data, } \\
\text { sketsa, gambar, analisis singkat dsb) }\end{array}$ \\
\hline 1. & 1 s.d. 10 & $\begin{array}{l}\text { Latihan dan praktik pemahaman } \\
\text { cerita Sarip ke anak-anak }\end{array}$ & $\begin{array}{l}\text { Anak-anak berlatih memerankan karakter } \\
\text { Sarip melalui media wayang (lampiran } \\
\text { 3.2) }\end{array}$ \\
\hline 2. & 11 s.d. 15 & $\begin{array}{l}\text { Menulis hasil praktik cerita } \\
\text { Sarip }\end{array}$ & $\begin{array}{l}\text { Penulisan hasil dan pembahasan tahap } \\
\text { pertama }\end{array}$ \\
\hline
\end{tabular}

Tabel 3: Luaran

\begin{tabular}{|c|c|c|c|}
\hline No. & Tanggal & Kegiatan & Catatan Kemajuan \\
\hline 1. & $\begin{array}{l}10 \\
\text { Februari } \\
2018\end{array}$ & Pementasan Wayang Sarip & $\begin{array}{l}\text { http://koran-sindo.com/page/news/2018- } \\
\text { 02- } \\
\text { 12/5/2/Ajak_Anak_anak_untuk_Antisipasi } \\
\text { Budaya_Lokal_Punah }\end{array}$ \\
\hline
\end{tabular}




\section{KESIMPULAN}

Proses yang telah dilakukan adalah pendekatan nilai-nilai edukasi moral dari cerita Sarip kepada anak-anak. Pendekatan moral tersebut juga belum sampai pada pemahaman yang terdalam masih dalam proses penciptaan pemupukan mental anakanak bahwa cerita rakyat merupakan hal yang menyenangkan untuk dipelajari. Proses selanjutnya yang diharapkan adalah pemahaman secara utuh tentang karakter Sarip sebagai ikon budaya bagi anak-anak. Pada tahap selanjutnya pementasan ini bisa juga digunakan dalam berbagai muatan misalnya: pelatihan bahasa Jawa atau bahasa lnggis melalui media pementasan Wayang Sarip, kampanye kebersihan lingkungan dengan media pementasan Wayang Sarip dan lain-lain, seperti pementasan wayang kulit purwa yang dapat membawa segala bentuk pesan moral.

\section{REFERENSI}

Hutomo, Suripan Sadi, dkk. 1984. Penelitian Bahasa dan Sastra Babad Demak Pesisiran. Jakarta: Pusat
Pembinaan dan Pengembangan Bahasa Departemen Pendidikan dan Kebudayaan.

Suherman, Djamil. 1985. SARIP TAMBAKOSO (Kisah kasih seorang Ibu). Jakarta: Mizan.

Sumarsam. 2003. Gamelan Interaksi Budaya dan Perkembangan Musikal di Jawa. Yogyakarta: Pustaka Pelajar

Suprajitno, S 2017, 'Teater sebagai Media untuk Pengabdian Masyarakat' Jurnal Pengabdian kepada Masyarakat Vol. 3, No.1 hh. 96 107

Susastina, Sukatmi. 2009. Tembang Macapat. Yogyakarta: Panji Pustaka

Susilo, J 2014, Spiritualitas Santri lelana pada Serat Mursada, (Tesis). Surabaya: Magister Kajian Sastra dan Budaya Universitas Airlangga.

Zaidan, dkk. 2002. Mitologi Jawa dalam Puisi Indonesia 1971 - 1990. Jakarta: Pusat Bahasa Departemen Pendidikan Nasional. 